\title{
Pengaruh Metode Iqra Terhadap Kemampuan Membaca Al- Qur'an Anak Usia Prasekolah
}

\author{
R. Ghefira Aulia Shafa ${ }^{1}$ \\ ${ }^{1}$ Prodi Bimbingan Penyuluhan Islam, Ciamis, STID Sirnarasa \\ auliashafaghefira@gmail.com.
}

\begin{abstract}
ABSTRAK
Penelitian ini bertujuan untuk mengetahui pengaruh bimbingan baca tulis metode iqra terhadap kemampuan membaca Al-Qur'an anak usia prasekolah di TK AlQur'an Nurul Huda. Penelitian ini menggunakan pendekatan kuantitatif dengan analisis data melalui software SPSS versi 22. Jumlah populasi anak sebanyak 52 orang dan peneliti mengambil total keseluruhan populasi sebagai sampel. Pengumpulan data menggunakan kuesioner dengan skala Likert. Dan hasil dari penelitian ini menunjukkan bahwa hipotesis nol $\left(\mathrm{H}_{0}\right)$ ditolak dan hipotesis kerja ( $\left.\mathrm{Ha}\right)$ diterima dengan menggunakan uji parsial dan uji simultan. Besar pengaruh antara variabel X terhadap variabel $\mathrm{Y}$ ialah $24,9 \%$ dengan nilai persamaan regresi $\mathrm{Y}=-24,846+1,285$ $\mathrm{X}$ yang mana menunjukan arah pengaruh yang positif.
\end{abstract}

Kata Kunci: Bimbingan, Baca Al-Qur'an, Anak Prasekolah

\begin{abstract}
This study aims to determine the effect of reading and writing guidance using the Iqra method on the ability to read the Qur'an of preschool-aged children in Nurul Huda Kindergarten. This study uses a quantitative approach with data analysis through SPSS version 22 software. The total population of children is 52 people and the researcher takes the total population as a sample. Collecting data using a questionnaire with a Likert scale. And the results of this study indicate that the null hypothesis $(\mathrm{HO})$ is rejected and the working hypothesis $(\mathrm{Ha})$ is accepted by using a partial test and simultaneous test. The magnitude of the influence between the $X$ variable on the $Y$ variable is $24.9 \%$ with the value of the regression
\end{abstract}

Diterima: Agustus 2021. Disetujui: September 2021. Dipublikasikan: September 2021 90 
Pengaruh Metode Iqra Terhadap Kemampuan Membaca Al-Qur'an Anak Usia Prasekolah equation $Y=-24.846+1.285 X$ which shows the direction of the positive influence.

Keywords: Guidance, Reading the Qur'an, Preschool Children

\section{PENDAHULUAN}

Menurut Kamus Besar Bahasa Indonesia (KBBI) anak adalah keturunan kedua. Dalam UU No. 35 tahun 2014 tentang Perubahan Atas UU No. 23 Tahun 2002 tentang Perlindungan Anak, dikatakan bahwa anak adalah individu yang berusia kurang dari 18 tahun, maupun yang masih berada dalam kandungan. Anak merupakan amanah dan karunia terbesar yang diberikan Alloh kepada orang tuanya untuk diarahkan, dididik, dan dibina dengan penuh kasih sayang. Anak akan menjadi sumber kebahagiaan orang tuanya bilamana ia tumbuh dan berkembang sesuai dengan harapan serta sejalan dengan aturan Alloh. Selain itu dijelaskan juga dalam UU No. 35 tahun 2014 tentang Perubahan Atas UU No. 23 Tahun 2002 tentang Perlindungan Anak bahwa anak sebagai generasi muda yang berperan dalam meneruskan cita-cita bangsa yang memiliki potensi dan sifat khusus yang perlu dirawat demi masa depan negara.

Diambil dari data APK Kementrian Pendidikan dan Kebudayaan Pusat Data dan Teknologi Informasi tahun 2020/2021 bahwa di Indonesia jumlah anak usia dini berjumlah 18.976 .000 jiwa, sedangkan untuk daerah Jawa Barat berjumlah 3.462.500 jiwa, dan di Kabupaten Ciamis berjumlah 137.856 jiwa (Data APK Kemendikbud, 2021: 1 dan 5).

Anak dilahirkan dengan berbagai potensi yang berbeda-beda. Anak sudah mulai belajar sejak ia lahir ke dunia dari lingkungan terdekatnya yaitu orang tua, dari mulai belajar berbicara, berjalan, makan, mandi, dan belajar untuk berteman serta bersosialisasi dengan baik. Tumbuh kembang anak tidak lepas dari peran orang tuanya, agar anak dapat menyelesaikan tugas perkembangannya dengan baik, maka orang tua sebagai guru pertama serta sebagai penanggung jawab harus sangat memperhatikan setiap aspek kehidupan anak. 
R. Ghefira AS,

Semakin bertambahnya usia anak, maka tugas perkembangannya pun akan berbeda. Dan disetiap tugas perkembangan anak tersebut tentunya harus terselesaikan dengan baik. Karena jika tidak, anak akan mengalami ketertinggalan dan kesulitan untuk menyelesaikan tugas perkembangan yang selanjutnya. Oleh karena itu agar setiap anak mampu menyelesaikan tugas perkembangannya dengan baik, maka ia perlu mengoptimalkan kemampuan yang ada dalam dirinya semaksimal mungkin dari segala aspek mulai dari fisik, mental, sosial, dan akhlaq.

Ketika anak mulai memasuki usia prasekolah maka mereka perlu pengetahuan yang lebih serta pengoptimalisasian potensi yang dimilikinya. Kewajiban orang tua untuk memberikan pendidikan pada anak selain pendidikan akhlaq dan tatakrama, perlu juga dibimbing untuk mampu membaca dan menulis. Karena kemampuan tersebut adalah kemampuan mendasar yang sangat penting dimiliki oleh setiap anak agar mampu beradaptasi dan berinteraksi dengan lingkungan.

Permasalahan yang terjadi di Desa Cibeureum khususnya orang tua wali santri TK Al-Qur'an Nurul Huda, bahwa para orang tua menginginkan anaknya mampu membaca dan menulis dengan baik terutama membaca Al-Qur'an sebelum nantinya melanjutkan pendidikan ke Sekolah Dasar. Namun sebagian dari orang tua tidak mampu mengajarkan anaknya dengan baik karena beberapa aspek seperti adanya keterbatasan waktu, pengetahuan orang tua yang tidak mumpuni dalam cara mengajar, anak tidak nurut dan sulit mengikuti ketika diberi arahan, sehingga sulit untuk mengajarkan anak membaca dan menulis jika hanya diajarkan oleh orang tuanya saja. Sehingga sebagian orang tua lebih memilih untuk menempatkan anak-anaknya di sekolah formal maupun non formal sejak dini agar anak-anak mereka mampu membaca serta menulis dengan baik karena dalam hal ini mereka perlu bantuan dari tenaga pengajar yang lebih berfokus pada tujuan tersebut.

Pemerintah mendirikan pendidikan untuk anak usia dini atau anak usia prasekolah, yang dimana di lembaga tersebut anak-anak akan diajarkan berbagai pengetahuan diantaranya membaca dan menulis. Lembaga 
Pengaruh Metode Iqra Terhadap Kemampuan Membaca Al-Qur'an Anak Usia Prasekolah pendidikan anak prasekolah ini merupakan upaya untuk pengoptimalisasian kemampuan dan pola pikir anak usia dini. Sehingga dengan adanya lembaga ini kewajiban orang tua dalam mendidik anak menjadi lebih ringan dan terbantu.

Ketika anak sudah berusia $4-6$ tahun, maka anak sudah bisa mengikuti pendidikan prasekolah yang diadakan oleh pemerintah seperti Pendidikan Anak Usia Dini (PAUD), Taman Kanak-Kanak (TK), Raudhatul Athfal (RA), Kelompok Bermain (Kober), dan lain sebagainya. Di Indonesia anak usia dini yang mengikuti pendidikan PAUD berjumlah 7.622.000 jiwa, sedangkan di Jawa Barat berjumlah 1.208.507 jiwa, dan di Kabupaten Ciamis berjumlah 37.505 jiwa (Data APK Kemendikbud, 2021: 1 dan 5).

Di TK Al-Qur'an Nurul Huda selain anak-anak diajarkan membaca dan menulis latin, terdapat bimbingan baca tulis Al-Qur'an yang menggunakan metode iqra dan dengan media buku Kibar. Disini anak dibimbing dari mulai mengenal huruf-huruf hijaiyah sampai mampu membaca Al-Qur'an. Keunikan yang peneliti temui di TK Al-Qur'an Nurul Huda ini ialah pihak terkait memiliki target pencapaian yaitu mencetak generasi yang mampu membaca Al-Qur'an di usia prasekolah dengan waktu belajar 1 tahun dan paling lambat 2 tahun. Hal ini memang sudah terbukti dari beberapa generasi TK Al-Qur'an Nurul Huda yang telah lulus mereka sudah mampu membaca Al-Qur'an sebelum melanjutkan pendidikan ke tingkat Sekolah Dasar.

Dari paparan diatas, maka permasalahan yang akan diteliti ialah pengaruh bimbingan baca tulis metode iqra terhadap kemampuan membaca Al-Qur'an anak usia prasekolah. Penelitian ini dilakukan di TK Al-Qur'an Nurul Huda Desa Cibeureum Kecamatan Sukamantri Kabupaten Ciamis Jawa Barat.

Meninjau dari penelitian Aan Solihati tahun 2018 tentang "Peningkatan Kemampuan Membaca Al-Qur'an Melalui Permainan Huruf Kartu Hijaiyah" dapat dilihat dari hasil kegiatan tindakan kelas siklus I dan siklus II yang dimana persentase angka siklus II lebih besar dari pada siklus I. Sehingga 
R. Ghefira AS,

dapat disimpulkan bahwa semua anak mengalami peningkatan dan memiliki keinginan untuk belajar, akan tetapi harus menggunakan teknik pembelajaran yang bervariasi agar pencapaian lebih efektif.

Penelitian Lys Nur Handayani dan Suismanto tahun 2018 tentang "Metode Sorogan dalam Meningkatkan Kemampuan Membaca Al-Qur'an Pada Anak" bahwa sebagian besar anak sudah mampu melampaui jilid pemula sehingga dapat dikatakan telah mencapai target yang diinginkan. Dapat dibuktikan dari hasil pembelajaran bahwa dari 45 anak terdapat 34 anak yang telah memenuhi target, 7 anak belum mencapai target yang diinginkan, dan 4 anak tanpa keterangan.

Penelitian Andre Lifian Fatha Kharisma tahun 2019 tentang "Upaya Meningkatkan Kemampuan Membaca Al-Qur'an Anak Usia dini Melalui Penerapan Metode Tartili di TK Darul Qur'an Al-Karim Karang Tengah Baturraden" dapat diambil kesimpulan bahwa upaya yang dilakukan ialah pada awal pembelajaran tartili anak dikenalkan macam-macam huruf hijaiyah, setiap hari anak-anak dibiasakan untuk membaca tartili secara bersama-sama dengan bimbingan ustadzah, untuk mengetahui pencapaian belajar anak dilakukan setoran tartili setiap hari, memberikan reward pada anak yang berprestasi, membaca ulang tartili, dan membuat pojok-pojok untuk pembelajaran agar lebih bervariasi seperti pojok tartili, pojok fonik, pojok hafalan, dan pojok motorik.

Penelitian Syaripuddin tahun 2016 tentang "Peningkatan Kemampuan Baca Al-Qur'an Melalui Metode Iqra di TPA Raudhatul Fitriyah Desa Simpang Dua Kecamatan Kluet Tengah Kabupaten Aceh Selatan" bahwa adanya peningkatan dengan hasil dari nilai para santri yang telah tercapai pada pre-test dengan rata-rata nilai $81,1 \%$ kemudian pada post-test rata-rata nilai meningkat menjadi $90 \%$. Selain dari hasil nilai yang didapat, aktivitas keseharian santri dan ustadz juga meningkat.

Penelitian Srijatun tahun 2017 tentang "Implementasi Pembelajaran Baca Tulis Al-Qur'an dengan Metode Iqra pada Anak Usia Dini di RA. Perwinda Slawi Kabupaten Tegal" dapat diambil kesimpulan bahwa bagi anak usia 
Pengaruh Metode Iqra Terhadap Kemampuan Membaca Al-Qur'an Anak Usia Prasekolah dini metode iqra sangatlah cocok untuk proses belajar baca Al-Qur'an, karena melalui metode ini anak dikenalkan pada huruf-huruf Al-Qur'an secara bertahap serta bunyi pada setiap huruf tersebut sehingga anak akan lebih mudah memahaminya.

Penelitian Muhammad Zakaria Ansori tahun 2020 tentang "Penerapan Metode Iqra dalam Meningkatkan Kemampuan Baca Iqra Anak Usia Dini di TK An-Najihah Kecamatan Kota Baru Kota Jambi" bahwa adanya peningkatan terhadap hasil belajar siswa. Pada siklus pertama nilai rata-rata mencapai $37 \%$, sedangkan pada siklus kedua mencapai $62 \%$, dan pada siklus ketiga mencapai $94 \%$, sehingga rata-rata nilai peningkatan peserta didik menjadi 80. Terdapat 15 orang siswa yang mencapai target atau tuntas, dan 1 orang yang tidak tuntas. Sehingga dapat disimpulkan bahwa penelitian ini tentunya berbeda dari penelitian-penelitian sebelumnya.

Adapun pertanyaan penelitian ialah: (1) Bagaimana program dan pelaksanaan bimbingan baca Al-Qur'an di TK Al-Qur'an Nurul Huda?, (2) Bagaimana faktor kendala yang dialami dalam kegiatan bimbingan baca Al-Qur'an di TK Al-Qur'an Nurul Huda?, (3) Bagaimana kemampuan membaca Al-Qur'an anak usia prasekolah di TK Al-Qur'an Nurul Huda?, dan (4) Bagaimana pengaruh atau hasil dari bimbingan baca tulis metode iqra terhadap kemampuan membaca Al-Qur'an anak usia prasekolah di TK Al-Qur' an Nurul Huda?.

Metode penelitian yang digunakan ialah penelitian kuantitatif dengan menggunakan kuisioner atau angket sebagai instrumen penelitian. Angket yang telah disebar kepada responden kemudian akan dihitung menggunakan skala likert. Sugiyono (2013: 134) memberikan pengertian tentang skala likert yang mana digunakan untuk mengukur sebuah fenomena sosial yang berkaitan dengan sikap, persepsi, serta pendapat seseorang maupun kelompok.

Tabel 1 : Skala Likert

\begin{tabular}{|l|l|l|}
\hline Pilihan Jawaban & Keterangan & Skor \\
\hline
\end{tabular}


R. Ghefira AS,

\begin{tabular}{|l|l|l|}
\hline Sangat Setuju & SS & 5 \\
\hline Setuju & S & 4 \\
\hline Ragu-ragu & R & 3 \\
\hline Tidak Setuju & TS & 2 \\
\hline Sangat Tidak Setuju & STS & 1 \\
\hline
\end{tabular}

Pada setiap item pernyataan favourabel nilai yang ditentukan untuk mengukur jawaban para responden yaitu dimulai dari angka 5, 4, 3, 2, dan 1 , dengan alternatif jawaban yang digunakan ialah $5=$ sangat setuju, $4=$ setuju, 3 = netral, 2 = tidak setuju, dan 1 = sangat tidak setuju. Sedangkan pada setiap item pernyataan unfavourabel nilai yang ditentukan untuk mengukur jawaban para responden yaitu dimulai dari angka 1, 2, 3, 4, dan 5, dengan alternatif jawaban yang digunakan ialah $1=$ sangat setuju, $2=$ setuju, $3=$ netral, $4=$ tidak setuju, dan $5=$ sangat tidak setuju.

Tabel 2 : Skor Alternatif Jawaban

\begin{tabular}{|l|l|l|}
\hline Alternatif Jawaban & Favourable & Unfavourable \\
\hline Sangat Setuju & 5 & 1 \\
\hline Setuju & 4 & 2 \\
\hline Ragu-ragu & 3 & 3 \\
\hline Tidak Setuju & 2 & 4 \\
\hline Sangat Tidak Setuju & 1 & 5 \\
\hline
\end{tabular}


Pengaruh Metode Iqra Terhadap Kemampuan Membaca Al-Qur'an Anak Usia Prasekolah Adapun hipotesis dari penelitian ini ialah: (1) Hipotesis nol (Ho): “Tidak adanya pengaruh bimbingan baca tulis metode iqra terhadap kelancaran membaca Al-Qur'an anak usia prasekolah di TK Al-Qur'an Nurul Huda", dan (2) Hipotesis kerja (Ha): "Adanya pengaruh bimbingan baca tulis metode iqra terhadap kelancaran membaca Al-Qur'an anak usia prasekolah di TK Al-Qur'an Nurul Huda".

\section{LANDASAN TEORITIS}

Berdasarkan pengertian dari KBBI, kata bimbingan memiliki arti petunjuk/penjelasan, cara mengerjakan sesuatu, tuntunan, pimpinan. Adapun beberapa ahli yang mengemukakan pengertian bimbingan, diantaranya menurut Hallen (2005: 3) bahwa bimbingan merupakan proses membantu individu dengan usaha sendiri dalam menemukan serta mengembangkan kemampuan atau potensi yang dimiliki untuk mencapai kebahagiaan pribadi dan bermanfaat bagi sosial.

Bimbingan formal telah dibentuk dan diprakarsai oleh Frank Parson sejak tahun 1908, yang kemudian berkembang dan ditekuni oleh para ahlinya sehingga memunculkan berbagai rumusan mengenai bimbingan yang sesuai dengan pelayanan bimbingan tersebut.

Bimbingan menurut Lefever diartikan sebagai bagian dari proses pendidikan yang diatur secara sistematis dalam upaya membantu pertumbuhan dan perkembangan kekuatan yang ada dalam diri anak untuk menentukan dan mengarahkan kehidupnya sehingga kelak dapat mempergunakan pengalamannya untuk membantu dan bermanfaat bagi masyarakat (Lefever, dalam Prayitno \& Erman Amti, 2004).

Dalam KBBI kata baca memiliki arti melihat serta memahami isi dari apa yang tertulis, bisa dengan melisankan atau hanya dalam hati. Sedangkan "mampu" berarti kuasa atau sanggup melakukan sesuatu. Sehingga kemampuan mempunyai arti kesanggupan, kecakapan, dan kekuatan.

Seperti kata pepatah bahwa "membaca adalah jendela ilmu", yang dimana dengan membaca manusia bisa mendapat berbagai ilmu dan 
R. Ghefira AS,

pengetahuan yang akan berguna bagi dirinya. Membaca merupakan sesuatu hal yang samgat penting bagi setiap manusia, karena membaca merupakan suatu kegiatan belajar yang bertujuan untuk mengerti dan memahami makna yang terdapat dalam tulisan. Membaca sudah menjadi perintah dari Allah SWT, sebagaimana dalam QS. Al-'Alaq ayat 1 yang juga merupakan wahyu pertama yang diturunkan kepada Nabi Muhammad SAW bahwa Allah memerintahkan untuk membaca karena dengan membaca Allah dapat memberikan pengetahuan yang belum diketahui.

Kata Al-Qur'an berasal dari bahasa Arab yang artinya sesuatu yang dibaca (Anshori, 2013: 17). Menurut M. Quraish Shihab, secara harfiyah Al-Qur'an ialah bacaan yang sempurna. Kata tersebut tentunya telah dipilih dan ditentukan Allah SWT untuk menamai bacaan yang sempurna lagi mulia. Karena tidak ada bacaan yang mampu menandingi Al-Qur'an semenjak manusia mengenal baca dan tulis (Shihab, 1996: 3).

Sedangkan menurut istilah Al-Qur'an ialah firman Allah SWT yang disampaikan kepada Nabi Muhammad SAW melalui Malaikat Jibril dengan redaksi langsung dari Allah SWT dan diterima oleh umat islam dari zaman ke zaman tanpa adanya perubahan sedikitpun (Anshori, 2013: 18).

Anak dapat dikategorikan kedalam usia prasekolah jika berusia antara 36 tahun. Pada usia ini anak-anak senang sekali berimajinasi dan mempercayai hal-hal yang tidak realistis seperti mereka memiliki kekuatan dan lain sebagainya. Diusia ini anak membangun control system atau sistem kontrol diri dimana mereka mampu berpakaian, makan, dan ke toilet sendiri (Potts \& Mandeleco, 2012).

Berdasarkan yang dikemukakan oleh Montessori (dalam Noorlaila, 2010), bahwa pada usia 3-6 tahun anak-anak sudah dapat diarahkan untuk diajari cara menulis dan membaca. Usia prasekolah ini merupakan masa yang sangat produktif untuk mengembangkan potensi dan kreativitas anak. 
Pengaruh Metode Iqra Terhadap Kemampuan Membaca Al-Qur'an Anak Usia Prasekolah

Menurut Ipah Syaripah (dalam DIKTAT LIQA YASBIQ, 2010: 11), beberapa ciri atau karakteristik umum anak usia TK tersebut, antara lain: energik dan aktif, sedang melambat dalam tingkat pertumbuhan fisik, masih mempergunakan gigi-gigi bayi mereka, masih membutuhkan 10 jam waktu untuk tidur, tertarik akan makanan, orientasi bermain, belajar tentang kerja sama dan berbagi, belajar menerima tanggung jawab pribadi dan kemandirian, responsive terhadap dorongan dan pujian, mengembangkan konsep diri, belajar mengungkapkan dan menggambarkan perasaan, pikiran, dan pengalaman, imajinatif, rasa ingin tahu yang alamiyah, mengembangkan bahasa lisan, belum mampu memfokuskan perhatian pada lebih dari satu hal sekaligus, persepsi yang masih terikat/terbatas, egosentris, mampu memahami konsep waktu saat ini, pembelajaran yang utuh/menyeluruh, belum mampu mempersiapkan kategori-katergori hierarkis yang luas.

Adapun tujuan dari bimbingan baca Al-Qur'an yang dikemukakan oleh Mustafa (2009: 124-125) adalah: anak mampu membaca Al-Qur'an dengan benar, memahami isi kandungan dan makna didalamnya, serta mampu mengucapkannya dengan fasih, anak mampu memahami dan merenungkan makna dari ayat-ayat yang dibacanya, memberikan pemahaman pada anak tentang arahan dan petunjuk dalam Al-Qur'an yang ditujukan untuk kebaikan manusia, memberikan pemahaman pada anak tentang hukum-hukum yang ada dalam Al-Qur'an dan mengajarkan untuk menyimpulkan kandungan ayat yang dibacanya, mendidik anak untuk selalu beradab sesuai Al-Qur'an dan membiasakannya sehingga menjadi tingkah laku kesehariannya, menanamkan aqidah islam dalam hati anak, sehingga membentuk jiwanya menjadi suci dan selalu taat akan perintah Allah SWT, mengajarkan untuk mengimani segala hal yang datang dari Al-Qur'an, dan menerima dengan akal, mendorong anak untuk senantiasa membaca Al-Qur'an dan memahami makna-maknanya, menghubungkan antara hukum dan petunjuk Al-Qur'an dengan kehidupan keseharian anak, sehingga dapat menjadi jalan keluar dalam permasalahan hidupnya. Disisi lain guru juga harus menjelaskan bahwa segala hal yang ada dalam Al-Qur'an merupakan penentu kebahagiaan di dunia dan akhirat. 
R. Ghefira AS,

Menurut Abdul Chaer (2013), terdapat tiga indikator mampu membaca Al-Qur'an yaitu:

\section{Kelancaran dan tartil membaca Al-Qur'an}

Poerwadarminta (2006: 559) memberikan pengertian bahwa lancar ialah tidak terputus-putus, kencang, cepat, dan juga fasih. Sehingga lancar dapat diartikan bahwa dalam pengucapannya tidak tersendat-sendat, cepat, dan juga fasih. Sedangkan tartil dapat diartikan jelas dan tepat dalam pengucapan bacaannya serta memiliki tempo yang sesuai sehingga huruf hijaiyah yang keluar tepat dengan kaidah tajwid yang ditentukan.

\section{Kesesuaian pelafalan huruf sesuai makhrajnya}

Agar tidak salah dalam pengucapan huruf sebaiknya mempelajari terlebih dahulu sifat-sifat huruf tersebut dan cara pelafalan yang benar. Makharijul huruf ialah membaca huruf Al-Qur'an sesuai dengan cara pelafalannya atau tempat keluarnya huruf seperti antara dua bibir, ditengah lidah, tenggorokan dan lain-lain (Abdul Majid, 2006).

\section{Ketepatan membaca Al-Qur'an sesuai tajwid}

Ilmu tajwid berguna untuk menjaga lidah kita dari kekeliruan/kesalahan ketika membaca Al-Qur'an. Sehingga sebelum membaca Al-Qur'an sebaiknya mempelajari ilmu tajwid terlebih dahulu. Ilmu tajwid adalah cara pelafalan setiap huruf Al-Qur'an berdasarkan sifat dan makhrajnya dengan benar sesuai kaidahnya (Hasanuddin, 1995).

Sikap atau tingkah laku dibentuk oleh keluarga, pendidikan, dan media. Sikap atau tingkah laku yang sering disebut behavioral ini merupakan teori yang mempelajari perilaku tentang tingkah laku manusia. Teori yang di kemukakan oleh John B. Watson (1913) dan B.F. Skinner ini memiliki perspektif yang berfokus pada peran dalam belajar, guna memodifikasi tingkah laku yang tidak diinginkan sehingga menekankan pada tingkah laku positif. Dalam hal ini yang menjadi fokus adalah anak, yang dimana anak dibimbing dan diajarkan membaca Al-Qur'an sejak 


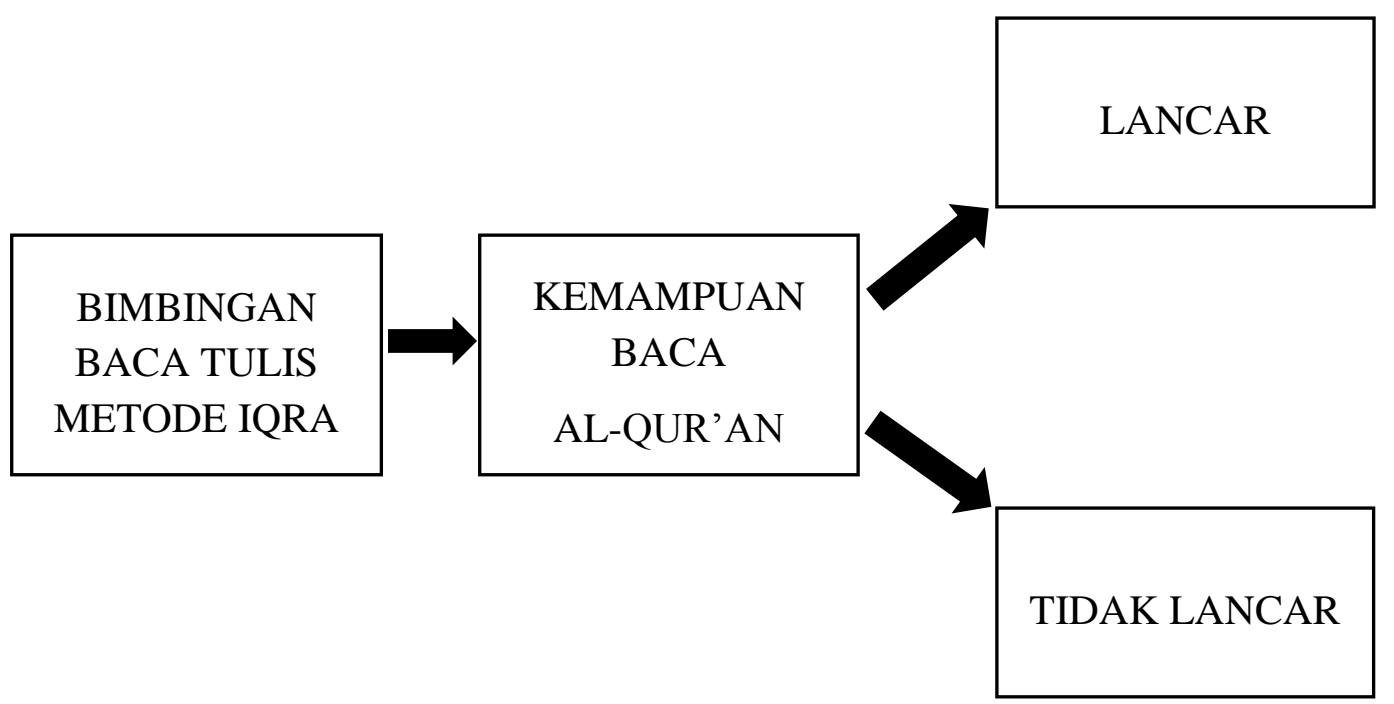

\section{HASIL DAN PEMBAHASAN}

TK Al-Qur'an Nurul Huda merupakan pendidikan formal untuk anak usia dini yang berada di Dusun Cibeureum RT 19 RW 20 Desa Cibeureum Kecamatan Sukamantri Kabupaten Ciamis Jawa Barat. Cikal bakal terbentuknya berawal sejak tahun 1992, yang dimana saat itu merupakan lembaga pendidikan non-formal untuk belajar mengaji bagi anak-anak usia dini atau biasa disebut juga dengan madrasah. Seiring berjalannya waktu dibuatkanlah Surat Keputusan (SK) pada tahun 2005.

TK Al-Qur'an Nurul Huda merupakan lembaga pendidikan yang berada dibawah naungan LPPTKA BKPRMI Kabupaten Ciamis yang mana merupakan lembaga pembina dari TK ini. Sedangkan untuk keberadaan organisasi kepengurusan dibawah Yayasan Al-Huda. Tenaga pengajar di TK Al-Qur'an Nurul Huda tahun 2020/2021 berjumlah 3 orang dan 1 kepala unit. Rata-rata pendidikan terakhir tenaga pengajar di TK AlQur'an Nurul Huda ialah SLTA dan Pesantren. Walaupun demikian semua tenaga pengajar tentunya sudah mengikuti banyak pelatihan yang 
R. Ghefira AS,

dibina oleh Lembaga Ilmu Al-Qur'an. Diantara lembaga yang rutin mengadakan pelatihan untuk tenaga pengajar yang sering diikuti oleh para pengajar TK Al-Qur'an Nurul Huda yaitu Lembaga Ilmu Al-Qur'an Indonesia Yayasan Bina Insan Qur'ani (LIQA-YASBIQ) Bandung yang juga merupakan lembaga yang bernaung dibawah LPPTKA BKPRMI.

Dalam wawancara bersama bapak kepala TK Al-Qur'an Nurul Huda bahwa: kriteria guru pembimbing menguasai ilmu tatacara baca AlQur'an, menguasai ilmu tajwid, menguasai metode pembelajaran iqra, memahami kurikulum, serta memiliki akhlaq mulia yang bisa dijadikan contoh bagi santri juga orang tua murid. Kurikulum yang digunakan di TK Al-Qur'an Nurul Huda ialah 60\% pembelajaran baca tulis Al-Qur'an dan $40 \%$ pengetahuan umum seperti membaca latin, menulis latin, dan komputer anak yaitu pengetahuan mendasar tentang komputer pada anak yang telah dikenalkan sejak tahun 2013.

Adapun visi misi dari TK Al-Qur'an Nurul Huda yang mana menginduk pada visi misi LPPTKA BKPRMI Nasional ialah sebagai berikut:

VISI : Membentuk generasi muslim yang fasih membaca Al-Qur'an, mandiri, dan berakhlaq Al-Qur'an.

MISI : (1) Menjadikan santri bisa membaca Al-Qur'an dengan fasih, (2) Menanamkan dan menumbuhkan dasar-dasar aqidah islamiyah dengan baik dan benar pada santri, (3) Menanamkan dan menumbuhkan dasardasar akhlaq islamiyah dengan baik dan benar pada santri, (4) Menanamkan dan menumbuhkan dasar-dasar adab Islamiyah dengan baik dan benar pada santri, (5) Menanamkan dan menumbuhkan dasardasar ibadah dengan baik dan benar pada santri, (6) Menanamkan dan menumbuhkan dasar-dasar kecakapan hidup (life skill) dengan baik dan benar kepada santri.

Merujuk pada program pemerintah Kabupaten Ciamis yang memiliki tujuan untuk membebaskan buta baca tulis huruf Al-Qur'an bagi masyarakat, TK Al-Qur'an Nurul Huda mengadakan bimbingan baca Al- 
Pengaruh Metode Iqra Terhadap Kemampuan Membaca Al-Qur'an Anak Usia Prasekolah Qur'an anak usia prasekolah bertujuan agar para generasi muda mampu membaca Al-Qur'an sejak dini sehingga dapat membantu mewujudkan program pemerintah tersebut.

Adapun daftar mana dan jabatan anggota yang berada di TK Al-Qur'an Nurul Huda ialah sebagaimana tabel berikut.

Tabel 3:

Daftar Nama dan Jabatan Anggota

\begin{tabular}{|l|l|l|}
\hline NO & \multicolumn{1}{|c|}{ NAMA } & \multicolumn{1}{|c|}{ JABATAN } \\
\hline 1. & H. Iyar Tamaswara, S.Ag. & Ketua Yayasan, Penasehat \\
\hline 1. & Abdullah Mubarak, S.HI. & $\begin{array}{l}\text { Kepala TK Al-Qur'an Nurul } \\
\text { Huda }\end{array}$ \\
\hline 2. & Siti Fatimah & Sekretaris, Tenaga Pengajar \\
\hline 3. & Dewi Indrawati & Bendahara, Tenaga Pengajar \\
\hline 4. & Popong & Tenaga Pengajar \\
\hline 5. & Iyan Supriatna & Tata Usaha \\
\hline 6. & Mamat Surahmat & Sarana dan Prasarana \\
\hline 7. & Harry Noor Alamsyah & Humas \\
\hline 8. & Ika Santika & Kesiswaan \\
\hline
\end{tabular}

Sumber : Arsip Dokumen TK Al-Qur'an Nurul Huda Tahun 2020/2021

\section{Deskripsi Data}


R. Ghefira AS,

Karakteristik Responden

Penelitian dilakukan dengan menyebar angket kepada 52 orang responden sebagai objek yang akan diteliti. Dari penyebaran angket tersebut sehingga diperoleh karakteristik responden yang terbagi berdasarkan usia, jenis kelamin, dan kelas.

Karakteristik Responden Menurut Jenis Kelamin

Adapun karakteristik responden menurut jenis kelamin anak ialah sebagaimana pada table berikut.

Tabel 4 :

Karakteristik Responden Menurut Jenis Kelamin

\begin{tabular}{|l|l|l|l|}
\hline NO & JENIS KELAMIN & FREKUENSI & PERSENTASE \\
\hline 1. & Laki-laki & 28 & $54 \%$ \\
\hline 2. & Perempuan & 24 & $46 \%$ \\
\hline Jumlah & 52 & $100 \%$ \\
\hline
\end{tabular}

Sumber : Data Register TK Al-Qur'an Nurul Huda Tahun 2020/2021

Merujuk Tabel 4, diketahui: Laki-laki 28 orang (54\%) dan perempuan 24 orang (46\%). Hal ini menunjukkan bahwa anak usia dini yang mengikuti pendidikan di TK Al-Qur'an Nurul Huda mayoritasnya adalah laki-laki yaitu $54 \%$ dari jumlah keseluruhan.

Karakteristik Responden Menurut Kelas

Tingkatan kelas di TK Al-Qur'an Nurul Huda terdapat tiga kelas yaitu kelas A, kelas B1, dan kelas B2 sebagaimana pada table berikut.

Tabel 5 :

Karakteristik Responden Menurut Kelas 
Pengaruh Metode Iqra Terhadap Kemampuan Membaca Al-Qur'an Anak Usia Prasekolah

\begin{tabular}{|l|l|l|l|}
\hline NO & KELAS & FREKUENSI & PERSENTASE \\
\hline 1. & Kelas A & 17 & $33 \%$ \\
\hline 2. & Kelas B1 & 11 & $21 \%$ \\
\hline 3. & Kelas B2 & 24 & $46 \%$ \\
\hline Jumlah & 52 & $100 \%$ \\
\hline
\end{tabular}

Sumber : Data Register TK Al-Qur'an Nurul Huda Tahun 2020/2021

Merujuk Tabel 5, diketahui: kelas A sebanyak 17 responden (33\%), kelas B1 sebanyak 11 responden (21\%), dan kelas B2 sebanyak 24 responden (46\%). Hal ini menunjukkan bahwa santri kelas B2 lebih banyak dari kelas lainnya yaitu $46 \%$ dari jumlah keseluruhan.

Karakteristik Responden Menurut Usia

Santri TK Al-Qur'an Nurul Huda berkisar pada usia 4 - 6 tahun sebagaimana pada table berikut.

Tabel 6:

Karakteristik Responden Menurut Usia

\begin{tabular}{|l|l|l|l|}
\hline NO & USIA & FREKUENSI & PERSENTASE \\
\hline 1. & 4 tahun & 5 & $10 \%$ \\
\hline 2. & 5 tahun & 18 & $35 \%$ \\
\hline 3. & 6 tahun & 29 & $56 \%$ \\
\hline Jumlah & 52 & $100 \%$ \\
\hline
\end{tabular}


R. Ghefira AS,

Sumber : Data Register TK Al-Qur'an Nurul Huda Tahun 2020/2021

Merujuk Tabel 6, diketahui: usia 4 tahun sebanyak 5 responden (10\%), usia 5 tahun sebanyak 18 responden (35\%), dan usia 6 tahun sebanyak 29 responden (56\%). Hal ini menunjukkan bahwa anak usia dini yang mengikuti pendidikan di TK Al-Qur'an Nurul Huda mayoritas berusia adalah 6 tahun yaitu 56\% dari jumlah keseluruhan.

Deskripsi Data Penelitian Distribusi Tanggapan Responden

Deskripsi data pada kuesioner penelitian ditabulasi dan dilakukan penskoran menggunakan skala likert. Skor untuk pernyataan favourabel sebagai berikut: 5 yang berarti sangat setuju, 4 yang berarti setuju, 3 yang berarti netral, 2 yang berarti tidak setuju, dan 1 yang berarti sangat tidak setuju.

Sedangkan skor untuk pernyataan unfavourabel adalah sebagai berikut: 1 yang berarti sangat setuju, 2 yang berarti setuju, 3 yang berarti netral, 4 yang berarti tidak setuju, dan 5 yang berarti sangat tidak setuju.

Berdasarkan sistem skoring di atas, yang terendah pada tiap butir pernyataan adalah 1 dan tertinggi adalah 5 dengan jumlah responden 52 orang, maka:

Skor terendah $=52 \times 1=52$ dan Skor tertinggi $=52 \times 5=260$

Dari skor di atas, diperoleh rentang skor $260-52=208$, dan panjang kelas interval $=208: 5=41,6$ yang dibulatkan menjadi 42 . Sehingga kelas interval untuk pernyataan favourabel ditetapkan sebagai berikut :

$52-94=$ Tidak Baik

$95-137=$ Kurang Baik

$138-180=$ Cukup Baik

$181-223=$ Baik

$224-266=$ Sangat Baik

Sedangkan kelas interval untuk pernyataan unfavourabel sebagai berikut: 
$52-94=$ Sangat Baik

$95-137=$ Baik

$138-180=$ Cukup Baik

$181-223=$ Kurang Baik

224-266= Tidak Baik

Perhitungan skor untuk pernyataan favourable menggunakan rumus sebagai berikut :

$$
\text { Skor }=(\mathrm{SS} \times 5)+(\mathrm{S} \times 4)+(\mathrm{R} \times 3)+(\mathrm{TS} \times 2)+(\mathrm{STS} \times 1)
$$

Sedangkan perhitungan skor untuk pernyataan unfavourable menggunakan rumus sebagai berikut :

$$
\text { Skor }=(\mathrm{SS} \times 1)+(\mathrm{S} \times 2)+(\mathrm{R} \times 3)+(\mathrm{TS} \times 4)+(\mathrm{STS} \times 5)
$$

Skor tersebut digunakan untuk menentukan baik tidaknya tanggapan responden mengenai variabel yang diteliti.

Distribusi Tanggapan Responden tentang Bimbingan Baca Baca Tulis Metode Iqra

Rekapitulasi tanggapan responden terhadap peryataan bimbingan baca tulis metode iqra dengan perhitungan skor:

Tabel 7 :

Deskripsi Data Penelitian Distribusi Tanggapan Responden Variabel X

\begin{tabular}{|l|l|l|l|l|l|l|l|l|}
\hline \multirow{2}{*}{ NO } & PERNYATAAN & \multicolumn{6}{|c|}{ ALTERNATIF JAWABAN } & \multirow{2}{*}{ SKOR } \\
\cline { 3 - 7 } & SS & S & R & T & STS & \\
\hline FAVOURABEL & $\begin{array}{l}\text { Guru selalu } \\
\text { memberikan } \\
\text { penjelasan dengan }\end{array}$ & 42 & 6 & 4 & 0 & 0 & 246 \\
\hline
\end{tabular}


R. Ghefira AS,

\begin{tabular}{|c|c|c|c|c|c|c|c|}
\hline & $\begin{array}{l}\text { detail dan mudah } \\
\text { dipahami anak }\end{array}$ & & & & & & \\
\hline 2 & $\begin{array}{l}\text { Guru memahami } \\
\text { karakter setiap anak } \\
\text { dan membimbing } \\
\text { dengan baik sesuai } \\
\text { karakter anak tersebut }\end{array}$ & 33 & 17 & 2 & 0 & 0 & 239 \\
\hline 3 & $\begin{array}{l}\text { Guru selalu } \\
\text { mengulang bab iqra } \\
\text { yang belum lancar } \\
\text { sampai anak benar- } \\
\text { benar paham }\end{array}$ & 33 & 19 & 0 & 0 & 0 & 241 \\
\hline 4 & $\begin{array}{l}\text { Guru memberikan } \\
\text { bimbingan lebih pada } \\
\text { anak yang tertinggal } \\
\text { agar mencapai target } \\
\text { mampu membaca Al- } \\
\text { Qur'an }\end{array}$ & 42 & 10 & 0 & 0 & 0 & 250 \\
\hline 5 & $\begin{array}{lr}\text { Guru } & \text { mampu } \\
\text { mengajarkan tilawah } \\
\text { membaca Al-Qur'an } \\
\text { pada anak }\end{array}$ & 16 & 36 & 0 & 0 & 0 & 224 \\
\hline 6 & $\begin{array}{l}\text { Guru } \\
\text { mengajarkan hukum } \\
\text { nun mati dan mad } \\
\text { dengan baik }\end{array}$ & 27 & 25 & 0 & 0 & 0 & 235 \\
\hline
\end{tabular}


Pengaruh Metode Iqra Terhadap Kemampuan Membaca Al-Qur'an Anak Usia Prasekolah

\begin{tabular}{|c|c|c|c|c|c|c|c|}
\hline 7 & $\begin{array}{l}\text { Guru membimbing } \\
\text { anak sampai benar- } \\
\text { benar faham dan } \\
\text { lancar membacanya }\end{array}$ & 12 & 31 & 9 & 0 & 0 & 211 \\
\hline 8 & 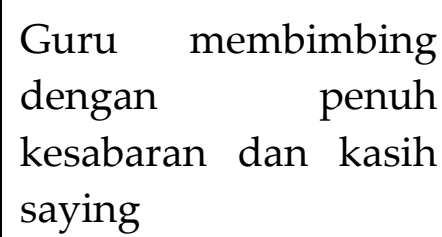 & 18 & 34 & 0 & 0 & 0 & 226 \\
\hline 9 & $\begin{array}{lr}\text { Anak selalu fokus } \\
\text { ketika sedang belajar } \\
\text { membaca Al-Qur'an } \\
\text { dan } & \text { selalu } \\
\text { memperhatikan guru } \\
\text { ketika } & \text { memberi } \\
\text { penjelasan } & \end{array}$ & 1 & 37 & 13 & 1 & 0 & 191 \\
\hline 10 & $\begin{array}{l}\text { Bimbingan baca Al- } \\
\text { Qur'an yang } \\
\text { dilakukan secara } \\
\text { langsung oleh guru } \\
\text { efektif meningkatkan } \\
\text { kemampuan baca Al- } \\
\text { Qur'an anak }\end{array}$ & 25 & 26 & 1 & 0 & 0 & 232 \\
\hline 11 & $\begin{array}{lr}\text { Tempat belajar yang } \\
\text { bersih dan menarik } \\
\text { membuat } & \text { anak } \\
\text { nyaman dan } & \text { betah } \\
\text { belajar } & \end{array}$ & 6 & 34 & 12 & 0 & 0 & 202 \\
\hline
\end{tabular}


R. Ghefira AS,

\begin{tabular}{|c|c|c|c|c|c|c|c|}
\hline 12 & $\begin{array}{l}\text { Buku iqra yang } \\
\text { digunakan dengan } \\
\text { jilid yang lebih singkat } \\
\text { mudah dipahami anak } \\
\text { dan mempercepat } \\
\text { anak mampu } \\
\text { membaca Al-Qur'an }\end{array}$ & 13 & 32 & 7 & 0 & 0 & 214 \\
\hline \multicolumn{8}{|c|}{ UNFAVOURABEL } \\
\hline 13 & $\begin{array}{lr}\text { Buku iqra yang } \\
\text { digunakan terlalu } \\
\text { singkat dan sulit } \\
\text { dipahami anak }\end{array}$ & 0 & 0 & 0 & 14 & 38 & 246 \\
\hline
\end{tabular}

Merujuk Tabel 7 di atas, diketahui bahwa untuk pernyataan favourable masing-masing pernyataan memiliki skor pada kisaran 224 - 266 dengan kategori sangat baik. Skor tertinggi responden pada varibel $X$ sebesar 250 pada butir pernyataan nomor 4 yaitu "Guru memberikan bimbingan lebih pada anak yang tertinggal agar mencapai target mampu membaca AlQur'an" dengan indikator menguasai metode bimbingan (kurikulum). Artinya, dalam proses bimbingan tersebut guru memahami bahwa target dari kurikulum yang digunakan ialah anak harus sudah mampu membaca Al-Qur'an sebelum kemudian melanjutkan pendidikan ke Sekolah Dasar.

Sedangkan untuk pernyataan unfavourable dengan satu pernyataan yang memiliki skor 246, dikategorikan pada kisaran skor 224 - 266 dengan kategori kurang baik. Dalam butir pernyataan nomor 13 bahwa "Buku iqra yang digunakan terlalu singkat dan sulit dipahami anak" dengan indikator media cetak yang digunakan, dapat diartikan bahwa buku iqra yang digunakan sangat baik dan mudah dipahami anak karena para responden menolak pernyataan bahwa buku iqra yang digunakan terlalu 
Pengaruh Metode Iqra Terhadap Kemampuan Membaca Al-Qur'an Anak Usia Prasekolah singkat dan sulit dipahami anak.

Distribusi Tanggapan Responden tentang Kemampuan Membaca AlQur'an Anak Usia Prasekolah

Rekapitulasi tanggapan responden terhadap peryataan kemampuan membaca Al-Qur'an anak usia prasekolah dengan perhitungan skor:

Tabel 8 :

Deskripsi Data Penelitian Distribusi Tanggapan Responden Variabel Y

\begin{tabular}{|l|l|l|l|l|l|l|l|l|}
\hline \multirow{2}{*}{$\begin{array}{l}\text { N } \\
\text { O }\end{array}$} & PERNYATAAN & \multicolumn{5}{|l|}{ ALTERNATIF JAWABAN } & \multirow{2}{*}{ SKOR } \\
\cline { 2 - 7 } 14 & SS & S & R & T & STS & \\
\hline FAVOURABEL & $\begin{array}{l}\text { Anak dapat langsung } \\
\text { mengucap bunyi huruf } \\
\text { hijaiyah yang ditunjuk } \\
\text { oleh guru dengan } \\
\text { benar }\end{array}$ & 22 & 22 & 6 & 2 & 0 & 220 \\
\hline 16 & $\begin{array}{l}\text { Anak dapat } \\
\text { membedakan bunyi } \\
\text { huruf hijaiyah yang } \\
\text { hampir sama dan } \\
\text { mengucapkannya } \\
\text { dengan benar }\end{array}$ & 15 & 24 & 12 & 1 & 0 & 209 \\
\hline 18 & $\begin{array}{l}\text { Anak dapat membaca } \\
\text { kalimat dalam Al- } \\
\text { Qur'an dengan lancar } \\
\text { dan tartil }\end{array}$ & 18 & 13 & 5 & 0 & 201 \\
\hline
\end{tabular}


R. Ghefira AS,

\begin{tabular}{|c|c|c|c|c|c|c|c|}
\hline 20 & $\begin{array}{lr}\text { Anak dapat membaca } \\
\text { huruf } \\
\text { sambung } \\
\text { benar }\end{array}$ & 23 & 14 & 5 & 1 & 0 & 188 \\
\hline 22 & $\begin{array}{l}\text { Anak memahami } \\
\text { bunyi idgham, ikhfa, } \\
\text { iqlab, idzhar dan } \\
\text { membacanya dengan } \\
\text { benar }\end{array}$ & 3 & 33 & 14 & 2 & 0 & 193 \\
\hline 24 & $\begin{array}{l}\text { Anak sangat } \\
\text { memperhatikan jika } \\
\text { ada tanda mad dan } \\
\text { dibaca panjang }\end{array}$ & 35 & 9 & 6 & 2 & 0 & 233 \\
\hline \multicolumn{8}{|c|}{ UNFAVOURABEL } \\
\hline 15 & $\begin{array}{lr}\text { Anak sering } & \text { lupa } \\
\text { bunyi huruf } & \text { hijaiyah } \\
\text { ketika } & \text { guru } \\
\text { mengajarkan } & \text { dengan } \\
\text { cara diacak } & \end{array}$ & 0 & 8 & 10 & 16 & 18 & 200 \\
\hline 17 & $\begin{array}{ll}\text { Anak sering } & \text { keliru } \\
\text { mengucapkan } & \text { bunyi } \\
\text { huruf hijaiyah } & \text { yang } \\
\text { hampir sama } & \end{array}$ & 0 & 5 & 13 & 21 & 13 & 198 \\
\hline 19 & $\begin{array}{l}\text { Anak masih tersendat- } \\
\text { sendat ketika membaca } \\
\text { Al-Qur'an }\end{array}$ & 1 & 12 & 8 & 17 & 14 & 187 \\
\hline
\end{tabular}


Pengaruh Metode Iqra Terhadap Kemampuan Membaca Al-Qur'an Anak Usia Prasekolah

\begin{tabular}{|l|l|l|l|l|l|l|l|}
\hline 21 & $\begin{array}{l}\text { Anak sering keliru } \\
\text { ketika membaca huruf } \\
\text { hijaiyah sambung }\end{array}$ & 0 & 2 & 7 & 12 & 29 & 218 \\
\hline 23 & $\begin{array}{l}\text { Anak sering keliru } \\
\text { ketika membedakan } \\
\text { bunyi bacaan idzhar, } \\
\text { idgham, ikhfa, dan } \\
\text { iqlab }\end{array}$ & 0 & 5 & 14 & 30 & 3 & 187 \\
\hline 25 & $\begin{array}{l}\text { Anak sering lupa } \\
\text { ketika ada tanda mad } \\
\text { untuk dibaca panjang }\end{array}$ & 0 & 3 & 6 & 9 & 34 & 230 \\
\hline
\end{tabular}

Merujuk Tabel 8 di atas, diketahui bahwa untuk pernyataan favourabel masing-masing pernyataan memiliki skor pada kisaran 224 - 266 dengan kategori sangat baik. Skor tertinggi responden pada varibel Y sebesar 233 pada butir pernyataan nomor 24 yaitu "Anak sangat memperhatikan jika ada tanda mad dan dibaca panjang" dengan indikator dapat membaca mad dengan benar. Artinya, anak sudah sangat paham dan mengerti hukum bacaan mad.

Sedangkan untuk pernyataan unfavourabel masing-masing pernyataan memiliki skor pada kisaran 224 - 266 dengan kategori kurang baik. Skor tertinggi responden pada varibel Y sebesar 230 pada butir pernyataan nomor 25 yaitu "Anak sering lupa ketika ada tanda mad untuk dibaca panjang" dengan indikator dapat membaca mad dengan benar. Artinya, anak sudah sangat paham dan mengerti hukum bacaan mad karena responden menolak pernyataan anak sering lupa ketika ada tanda mad untuk dibaca panjang.

Pengujian Persyaratan Analisis

Uji Instrumen Penelitian

Uji Validitas 
R. Ghefira AS,

Untuk penelitian ini digunakan r-tabel 50 dengan tingkat signifikansi 0,05 yang didapat dari rumus degree of freedom (df) $=52-2=50$ dan nilai dari r-tabel 50 yaitu 0,273 yang digunakan sebagai acuan dalam mencari validitas. Dapat dikatakan valid apabila r-hitung $>0,273$ (r-tabel) dan sebaliknya jika r-hitung < 0,273 (r-tabel) maka item pernyataan dikatakan drop atau tidak valid.

Tabel 9:

Uji Validitas

\begin{tabular}{|l|l|l|l|l|}
\hline Pernyataan & r Hitung & Sig & r Tabel & Keterangan \\
\hline 1 & $0,288^{*}$ & 0,038 & 0,273 & VALID \\
\hline 2 & $0,336^{*}$ & 0,015 & 0,273 & VALID \\
\hline 3 & $0,462^{* *}$ & 0,001 & 0,273 & VALID \\
\hline 4 & $0,297^{*}$ & 0,033 & 0,273 & VALID \\
\hline 5 & $0,477^{* *}$ & 0,000 & 0,273 & VALID \\
\hline 6 & $0,363^{* *}$ & 0,008 & 0,273 & VALID \\
\hline 7 & $0,298^{*}$ & 0,032 & 0,273 & VALID \\
\hline 8 & $0,328^{*}$ & 0,018 & 0,273 & VALID \\
\hline 9 & $0,714^{* *}$ & 0,000 & 0,273 & VALID \\
\hline 10 & 0,062 & 0,664 & 0,273 & DROP \\
\hline 11 & $0,342^{*}$ & 0,013 & 0,273 & VALID \\
\hline
\end{tabular}




\begin{tabular}{|c|c|c|c|c|}
\hline 12 & 0,132 & 0,352 & 0,273 & DROP \\
\hline 13 & $0,299^{*}$ & 0,031 & 0,273 & VALID \\
\hline 14 & 0,053 & 0,710 & 0,273 & DROP \\
\hline 15 & $0,281^{*}$ & 0,043 & 0,273 & VALID \\
\hline 16 & $0,369^{* *}$ & 0,007 & 0,273 & VALID \\
\hline 17 & $0,746^{* *}$ & 0,000 & 0,273 & VALID \\
\hline 18 & $0,780^{* *}$ & 0,000 & 0,273 & VALID \\
\hline 19 & $0,816^{* *}$ & 0,000 & 0,273 & VALID \\
\hline 20 & $0,822^{* *}$ & 0,000 & 0,273 & VALID \\
\hline 21 & $0,817^{* *}$ & 0,000 & 0,273 & VALID \\
\hline 22 & $0,762^{* *}$ & 0,000 & 0,273 & VALID \\
\hline 23 & $0,813^{* *}$ & 0,000 & 0,273 & VALID \\
\hline 24 & $0,864^{* *}$ & 0,000 & 0,273 & VALID \\
\hline 25 & $0,756^{* *}$ & 0,000 & 0,273 & VALID \\
\hline 26 & $0,748^{* *}$ & 0,000 & 0,273 & VALID \\
\hline 27 & $0,772^{* *}$ & 0,000 & 0,273 & VALID \\
\hline
\end{tabular}


R. Ghefira AS,

\begin{tabular}{|l|l|l|l|l|}
28 & $0,726^{* *}$ & 0,000 & 0,273 & VALID \\
\hline
\end{tabular}

Berdasarkan Tabel 9 diatas untuk uji validitas terdapat 25 butir valid, sedangkan 3 butir lainnya yaitu item pernyataan nomor 10, 12, dan 14 tidak valid atau drop karena r-hitung $<$ r-tabel.

Uji Reliabilitas

Pengujian reliabilitas instrumen dilakukan dengan menghitung skor pada setiap item dengan menggunakan perhitungan teknik Cronbach Alpha melalui program SPPS. Instrumen dapat dikatakan reliabel apabila menghasilkan nilai Cronbach Alpha $(\alpha)>0,60$.

Tabel 10 :

Uji Reliabilitas

Case Processing Summary

\begin{tabular}{|ll|l|l|}
\hline & $\mathrm{N}$ & $\%$ \\
\hline Cases & Valid & 52 & 100.0 \\
& Excludeda & 0 & .0 \\
& Total & 52 & 100.0 \\
\hline
\end{tabular}

a. Daftar penghapusan bijaksana berdasarkan semua variabel dalam prosedur. 


\section{Reliability Statistics}

\begin{tabular}{|l|l|}
\hline $\begin{array}{l}\text { Cronbach's } \\
\text { Alpha }\end{array}$ & N of Items \\
\hline .926 & 25 \\
\hline
\end{tabular}

Berdasarkan Tabel 10 terlihat bahwa Cronbach's Alpha mempunyai nilai sebesar 0,926>0,600 yang artinya instrumen tersebut adalah reliabel.

Uji Asumsi Dasar

Uji Normalitas

Uji Normalitas ini digunakan dengan tujuan untuk menguji sampel apakah memiliki distribusi normal atau tidak. Jika signifikansi $>0,05$, maka sampel yang digunakan berdistribusi normal. Sedangkan jika signifikansi $<0,05$, maka sampel yang digunakan tidak berdistribusi normal. Berdasarkan hasil perhitungan uji didapat hasil sebagaimana berikut.

Tabel 11 :

Uji Normalitas

One-Sample Kolmogorov-Smirnov Test

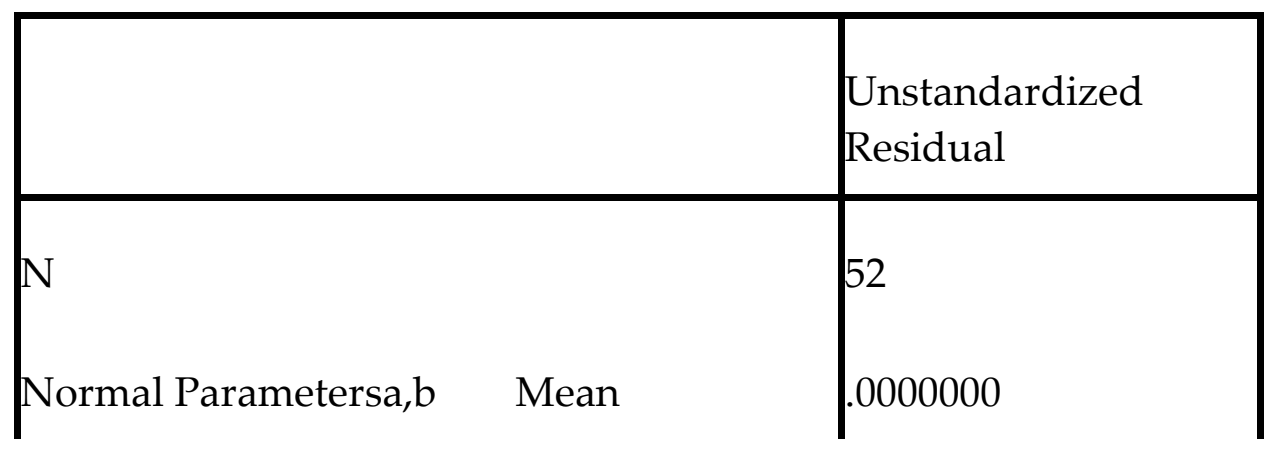


R. Ghefira AS,

\begin{tabular}{|l|l|l|} 
& Std. Deviation & 7.63353784 \\
Most Extreme Differences & Absolute & .060 \\
& Positive & .060 \\
& Negative & -.055 \\
Test Statistic & \\
Asymp. Sig. (2-tailed) & & .060 \\
\hline
\end{tabular}

a. Distribusi tes normal.

b. Dihitung dari data.

c. Koreksi signifikansi lilliefors.

d. Batas bawah dari nilai sebenarnya.

Berdasarkan hasil diatas nilai sig. $\mathrm{KS}=0,200$ yang mana lebih besar dari sig. KS $(\alpha=0,05)$. Sehingga dapat disampaikan bahwa keseluruhan populasi berdistribusi normal.

Uji Linieritas

Untuk menyatakan linieritas garis regresi yaitu dengan menggunakan nilai koefisien signifikansi dari Deviation from linierity kemudian dibandingkan dengan nilai alpha yang ditentukan yaitu 0,05. Apabila nilai Signifikansi Deviation from linierity $>0,05$ maka terdapat hubungan yang linier. Sedangkan apabila nilai Signifikansi Deviation from linierity $<0,05$ maka tidak terdapat hubungan yang linier. 
Tabel 12 :

Uji Linieritas

ANOVA Table

\begin{tabular}{|r|l|l|l|l|l|}
\hline & $\begin{array}{l}\text { Sum of } \\
\text { Squares }\end{array}$ & df & $\begin{array}{l}\text { Mean } \\
\text { Square }\end{array}$ & F & Sig. \\
\hline $\begin{array}{c}\text { Membaca *Between (Combined) } \\
\text { Bimbingan Groups }\end{array}$ & 2182.810 & 14 & 155.915 & 3.247 & .002 \\
Linierity & 987.626 & 1 & 987.626 & 20.568 & .000 \\
$\begin{array}{c}\text { Deviation } \\
\text { Linierity }\end{array}$ & 1195.184 & 13 & 91.937 & 1.915 & .061 \\
\hline $\begin{array}{c}\text { Within Groups } \\
\text { Total } \quad 1776.632\end{array}$ & 37 & 48.017 & & \\
\hline
\end{tabular}

Dari hasil olah data dan mendapatkan nilai Sig. Deviation from linierity adalah 0,061 maka otomatis hubungan antara variabel bebas dengan variabel terikat adalah linier secara signifikan, karena 0,061 >0,05.

Pengujian Hipotesis

Uji Parsial (Uji t)

Uji parsial memiliki ketentuan jika nilai t hitung > t tabel, maka H0 ditolak dan Ha diterima. Sedangkan jika nilai t hitung $<\mathrm{t}$ tabel, maka H0 diterima dan Ha ditolak dengan nilai $t$ tabel 2,008.

Tabel 13:

Uji Parsial (Uji t) 
Coefficientsa

\begin{tabular}{|c|c|c|c|c|c|}
\hline \multirow[b]{2}{*}{ Model } & \multicolumn{2}{|c|}{$\begin{array}{l}\text { Unstandardized } \\
\text { Coefficients }\end{array}$} & \multirow{2}{*}{$\begin{array}{l}\text { Standardized } \\
\text { Coefficients }\end{array}$} & \multirow[b]{2}{*}{$T$} & \multirow[b]{2}{*}{ Sig. } \\
\hline & $B$ & Std. Error & & & \\
\hline $1 \quad$ (Constant) & -24.845 & 17.982 & & -1.382 & .173 \\
\hline Bimbingan & 1.285 & .315 & .499 & 4.076 & .000 \\
\hline
\end{tabular}

Dari hasil olah data diatas maka didapat nilai $t$ hitung sebesar 4,076 sehingga disimpulkan bahwa $\mathrm{H} 0$ ditolak dan Ha diterima, karena sesuai dengan kriteria yaitu 4,076 ( $\mathrm{t}$ hitung) $>2,008$ ( $\mathrm{t}$ tabel).

Uji Simultan (Uji F)

Uji simultan memiliki ketentuan jika $\mathrm{F}$ hitung $<\mathrm{F}$ tabel maka $\mathrm{H} 0$ diterima dan Ha ditolak. Dan jika F hitung $>$ F tabel maka H0 ditolak dan Ha diterima dengan nilai $\mathrm{F}$ tabel 4,03.

Tabel 14 :

Uji Simultan (Uji F)

ANOVAa

\begin{tabular}{|c|c|c|c|c|c|}
\hline Model & $\mid \begin{array}{ll}\text { Sum } & \text { of } \\
\text { Squares } & \end{array}$ & Df & $\begin{array}{l}\text { Mean } \\
\text { Square }\end{array}$ & $F$ & Sig. \\
\hline
\end{tabular}


Pengaruh Metode Iqra Terhadap Kemampuan Membaca Al-Qur'an Anak Usia Prasekolah

\begin{tabular}{|ll|l|l|l|l|l|}
\hline 1 & Regression & 987.626 & 1 & 987.626 & 16.617 & $.000 \mathrm{~b}$ \\
& Residual & 2971.816 & 50 & 59.436 & & \\
Total & 3959.442 & 51 & & & \\
\hline
\end{tabular}

Dari hasil olah data diatas maka didapat nilai $\mathrm{F}$ hitung sebesar 16,617 maka dapat diambil kesimpulan bahwa H0 ditolak dan Ha diterima, karena sesuai dengan kriteria yaitu 16,617 (F hitung) > 4,03 (F tabel) menunjukkan bahwa variabel bebas mempunyai pengaruh kepada variabel terikat.

Koefisien Determinasi (R2)

Koefisien determinasi digunakan untuk mengetahui seberapa besar pengaruh yang diberikan variabel bebas pada variabel terikat.

Tabel 15 :

Koefisien Determinasi (R2)

Model Summary

\begin{tabular}{|l|l|l|l|l|}
\hline Model & $R$ & R Square & $\begin{array}{l}\text { Adjusted } \\
\text { Square }\end{array}$ & $\begin{array}{r}\text { Std. Error of } \\
\text { the Estimate }\end{array}$ \\
\hline 1 & $.499 \mathrm{a}$ & .249 & .234 & 7.70950 \\
\hline
\end{tabular}

Dari hasil diatas, diperoleh koefisien determinasi (R2) sebesar 0,249 $(24,9 \%)$. Hal ini menunjukkan bahwa pengaruh variabel bebas (Bimbingan) terhadap variabel terikat (Kemampuan baca) adalah sebesar $24,9 \%$. 
R. Ghefira AS,

Analisis Regresi Sederhana

Analisis regresi sederhana memiliki tujuan untuk menguji pengaruh antara variabel independen $(X)$ terhadap variabel dependen $(Y)$, yang mana variabel $X$ ialah yang mempengaruhi sedangkan variabel $Y$ yang dipengaruhi. Model persamaan regresi linier sederhana dengan rumus $Y$ $=\mathrm{a}+\mathrm{b}$ X adalah:

Tabel 16:

Analisis Regresi Sederhana

Coefficientsa

\begin{tabular}{|c|c|c|c|c|c|}
\hline \multirow[b]{2}{*}{ Model } & \multicolumn{2}{|c|}{$\begin{array}{l}\text { Unstandardized } \\
\text { Coefficients }\end{array}$} & \multirow{2}{*}{ 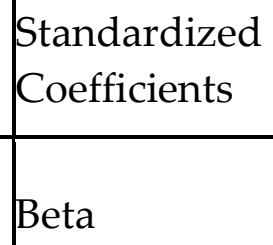 } & \multirow[b]{2}{*}{$T$} & \multirow[b]{2}{*}{ Sig. } \\
\hline & $B$ & Std. Error & & & \\
\hline 1 (Constant) & -24.845 & 17.982 & & -1.382 & .173 \\
\hline Bimbingan & 1.285 & .315 & .499 & 4.076 & .000 \\
\hline
\end{tabular}

Diketahui nilai konstanta (a) sebesar -24,846, sedangkan nilai Bimbingan (b) koefisien regresi sebesar 1,285 sehingga: $Y=-24,846+1,285 X$.

\section{Program dan Pelaksanaan Bimbingan Baca Al-Qur'an di TK Al-Qur'an Nurul Huda}

TK Al-Qur'an Nurul Huda memiliki program unggulan yaitu bimbingan baca Al-Qur'an bagi anak usia prasekolah. Bimbingan baca Al-Qur'an di TK Al-Qur'an Nurul Huda menggunakan metode privat atau sorogan dimana santri dibimbing secara perorangan sesuai tingkatannya. Bimbingan baca Al-Qur'an di TK Al-Qur'an Nurul Huda ini menggunakan metode iqra dengan sarana yang digunakan yaitu buku 
Pengaruh Metode Iqra Terhadap Kemampuan Membaca Al-Qur'an Anak Usia Prasekolah

Kibar dengan 3 jilid dan masing-masing 38 halaman, yang mana merupakan inovasi baru dari iqra.

Pelaksanaan bimbingan baca Al-Qur'an melalui beberapa tahapan, yaitu: (1) Pengenalan huruf hijaiyah pada santri dan cara membacanya sesuai kaidah yang ditentukan, (2) Menjelaskan perbedaan cara pelafalan bunyi huruf hijaiyah, (3) Cara membaca huruf hijaiyah sambung, (4) Cara membaca Al-Qur'an langsung dengan kaidah dan bacaan tajwidnya, (5) Mengajarkan dan membiasakan anak membaca Al-Qur'an dengan tilawah.

Pengajaran hukum bacaan tajwid pada anak-anak diajarkan dengan menunjukan bentuk huruf dan syakalnya tanpa harus menyebutkan nama dari hukum bacaan tersebut. Misalnya dalam kalimat ada mad thobi'i dan harus dibaca panjang, guru hanya mempraktikan langsung cara bacanya dan tandanya tanpa harus menyebutkan bahwa yang demikian disebut mad thobi'i.

Santri bisa dinyatakan mampu baca Al-Qur'an jika telah memenuhi kriteria yang ditentukan oleh kurikulum sehingga dapat mengikuti ujian munaqasyah yang diselengkarakan oleh LPPTKA BKPRMI melalui Tim Munaqisy yang sudah disertifikasi oleh LPPTKA BKPRMI Kabupaten Ciamis.

\section{Faktor Kendala Pelaksanaan Kegiatan Bimbingan Baca Al-Qur'an di TK Al-Qur'an Nurul Huda}

Dalam pelaksanaan kegiatan bimbingan baca Al-Qur'an di TK Al-Qur'an Nurul Huda tentunya terdapat beberapa aspek yang menghambat jalannya proses pelaksanaan kegiatan tersebut. Adapun faktor kendalanya ialah: (1) Minimnya alat peraga sebagai media bantuan untuk proses belajar mengajar menjadi faktor kendala ketika guru ingin memberikan penjelasan terkait sesuatu yang membutuhkan alat tersebut, sehingga penyampaian materi kurang efektif, (2) Anak yang sulit dipisahkan dari orang tuanya karena pola asuh di rumah yang sudah tertanam sejak kecil, sehingga mengakibatkan anak menjadi kurang fokus 
R. Ghefira AS,

dalam belajar dan kurang mandiri, (3) Kurangnya mengikuti program peningkatan kapasitas pengajar sehingga guru menjadi kekurangan referensi dalam proses mengajar anak yang mengakibatkan situasi kelas menjadi jenuh dan bosan karena tidak ada hal baru dalam proses belajar mengajar, dan (4) Adanya pandemi covid-19 yang mengakibatkan pembatasan pembelajaran sehingga proses belajar mengajar tidak efektif.

Kemampuan Membaca Al-Qur'an Anak Usia Prasekolah di TK Al-Qur'an Nurul Huda

Kemampuan membaca Al-Qur'an anak di TK Al-Qur'an Nurul Huda sebagaimana data yang telah disajikan sebelumnya dan dengan penilaian skor yang sudah ditetapkan, sehingga dapat dinilai sebagai berikut:

Dapat mengucap huruf hijaiyah yang baik dan benar

Diketahui bahwa untuk pernyataan favourabel nomor 14 yaitu "Anak dapat langsung mengucap bunyi huruf hijaiyah yang ditunjuk oleh guru dengan benar" dengan skor nilai sebesar 220 dapat dikategorikan baik karena berada pada kisaran skor antara 181 - 223. Artinya, anak sudah mengenal dan mengetahui huruf hijaiyah dengan baik.

Sedangkan untuk pernyataan unfavourabel nomor 15 yaitu "Anak sering lupa bunyi huruf hijaiyah ketika guru mengajarkan dengan cara diacak" dengan skor nilai sebesar 200 dapat dikategorikan kurang baik karena berada pada kisaran skor antara 181 - 223. Artinya, anak sudah mengenal dan mengetahui huruf hijaiyah dengan baik karena responden menolak pernyataan anak sering lupa bunyi huruf hijaiyah ketika guru mengajarkan dengan cara diacak.

Dapat membedakan huruf hijaiyah yang hampir sama

Diketahui bahwa untuk pernyataan favourabel nomor 16 yaitu "Anak dapat membedakan bunyi huruf hijaiyah yang hampir sama dan mengucapkannya dengan benar" dengan skor nilai sebesar 209 dapat dikategorikan baik karena berada pada kisaran skor antara 181 - 223. 
Pengaruh Metode Iqra Terhadap Kemampuan Membaca Al-Qur'an Anak Usia Prasekolah Artinya, anak sudah mampu membedakan bunyi dan mengucapkan bunyi huruf hijaiyah dengan benar sesuai kaidahnya.

Sedangkan untuk pernyataan unfavourabel nomor 17 yaitu "Anak sering keliru mengucapkan bunyi huruf hijaiyah yang hampir sama" dengan skor nilai sebesar 198 dapat dikategorikan kurang baik karena berada pada kisaran skor antara 181 - 223. Artinya, anak sudah mampu membedakan bunyi dan mengucapkan bunyi huruf hijaiyah dengan benar sesuai kaidahnya tanpa keliru karena responden menolak pernyataan anak sering keliru mengucapkan bunyi huruf hijaiyah yang hampir sama.

Dapat membaca dengan lancar, jelas, dan benar

Diketahui bahwa untuk pernyataan favourabel nomor 18 yaitu "Anak dapat membaca kalimat dalam Al-Qur'an dengan lancar dan tartil" dengan skor nilai sebesar 201 dapat dikategorikan baik karena berada pada kisaran skor antara 181 - 223. Artinya, anak sudah mampu membaca Al-Qur'an dengan lancar tanpa tersendat-sendat dan juga tartil dalam pelafalannya.

Sedangkan untuk pernyataan unfavourabel nomor 19 yaitu "Anak masih tersendat-sendat ketika membaca Al-Qur'an" dengan skor nilai sebesar 187 dapat dikategorikan kurang baik karena berada pada kisaran skor antara 181 - 223. Artinya, anak sudah mampu membaca Al-Qur'an dengan lancar tanpa tersendat-sendat dan juga tartil dalam pelafalannya karena responden menolak pernyataan anak masih tersendat-sendat ketika membaca Al-Qur'an.

Dapat merangkai kata perkata dengan benar

Diketahui bahwa untuk pernyataan favourabel nomor 20 yaitu "Anak dapat membaca huruf hijaiyah sambung dengan benar" dengan skor nilai sebesar 188 dapat dikategorikan baik karena berada pada kisaran skor antara 181 - 223. Artinya, anak sudah mampu membaca kata perkata dalam kalimat Al-Qur'an. 
R. Ghefira AS,

Sedangkan untuk pernyataan unfavourabel nomor 21 yaitu "Anak sering keliru ketika membaca huruf hijaiyah sambung" yang memiliki skor nilai sebesar 218 dapat dikategorikan kurang baik karena berada pada kisaran skor antara 181 - 223. Artinya, anak sudah mampu membaca kata perkata dalam kalimat Al-Qur'an karena responden menolak pernyataan anak sering keliru ketika membaca huruf hijaiyah sambung.

Mengerti hukum nun mati dengan benar

Diketahui bahwa untuk pernyataan favourabel nomor 22 yaitu "Anak memahami bunyi idgham, ikhfa, iqlab, idzhar dan membacanya dengan benar" dengan skor nilai sebesar 193 dapat dikategorikan baik karena berada pada kisaran skor antara 181 - 223. Artinya, ketika membaca AlQur'an anak sudah mampu melafalkan bunyi yang seharusnya diucapkan jika bertemu hukum nun mati pada kalimat Al-Qur'an.

Sedangkan untuk pernyataan unfavourabel nomor 23 yaitu "Anak sering keliru ketika membedakan bunyi bacaan idzhar, idgham, ikhfa, dan iqlab" yang memiliki skor nilai sebesar 187 dapat dikategorikan kurang baik karena berada pada kisaran skor antara 181 - 223. Artinya, ketika membaca Al-Qur'an anak sudah mampu melafalkan bunyi yang seharusnya diucapkan jika bertemu hukum nun mati pada kalimat AlQur'an karena responden menolak pernyataan anak sering keliru ketika membedakan bunyi bacaan idzhar, idgham, ikhfa, dan iqlab.

Dapat membaca mad dengan benar

Diketahui bahwa untuk pernyataan favourabel nomor 24 yaitu "Anak sangat memperhatikan jika ada tanda mad dan dibaca panjang" yang memiliki skor nilai sebesar 233 dapat dikategorikan sangat baik karena berada pada kisaran skor antara 224 - 266. Artinya, anak sudah sangat paham dan mengerti tentang hukum bacaan mad.

Sedangkan untuk pernyataan unfavourabel nomor 25 yaitu "Anak sering lupa ketika ada tanda mad untuk dibaca panjang" yang memiliki skor nilai sebesar 230 dapat dikategorikan tidak baik karena berada pada 
Pengaruh Metode Iqra Terhadap Kemampuan Membaca Al-Qur'an Anak Usia Prasekolah kisaran skor antara 224 - 266. Artinya, anak sudah sangat paham dan mengerti tentang hukum bacaan mad karena responden menolak pernyataan anak sering lupa ketika ada tanda mad untuk dibaca panjang.

Pengaruh atau Hasil Bimbingan Baca Tulis Metode Iqra terhadap Kemampuan Membaca Al-Qur'an Anak Usia Prasekolah

Dilihat dari hasil pengolahan data dapat disimpulkan bahwa bimbingan baca tulis metode iqra memiliki pengaruh terhadap kemampuan membaca Al-Qur'an anak usia prasekolah. Dengan besar pengaruhnya adalah sebesar 24,9\%. Yang berarti bimbingan tersebut memiliki pengaruh yang positif kepada para santri sehingga mampu membaca AlQur'an sejak dini. Dikatakan positif karena menurut hasil pengolahan data didapatkan nilai persamaan regresi $Y=-24,846+1,285 X$. Maksudnya adalah nilai konsistensi variabel Y (kemampuan baca Al-Qur'an) sebesar -24,846 dan koefisien regresi variabel X (bimbingan baca Al-Qur'an) sebesar 1,285 yang mana setiap penambahan $1 \%$ nilai bimbingan, maka nilai kemampuan baca Al-Qur'an bertambah sebesar 1,285.

\section{PENUTUP}

Program bimbingan baca Al- Qur'an di TK Al-Qur'an Nurul Huda menggunakan metode iqra sedangkan untuk metode pembelajarannya menggunakan dua metode yaitu metode classical dan juga metode privat atau sorogan, dengan sarana yang digunakan yaitu buku Kibar dengan 3 jilid dan masing-masing 38 halaman, yang mana merupakan inovasi baru dari iqra.

Santri TK Al-Qur'an Nurul Huda bisa dikatakan kemampuan baca AlQur'annya sudah baik. Hal tersebut berdasarkan rata-rata nilai yang berkisar pada skor 181 - 223 dan dikategorikan baik.

Besar pengaruh antara bimbingan baca tulis metode iqra (variabel $\mathrm{X}$ ) terhadap kemampuan membaca Al-Qur'an anak usia prasekolah (variabel $Y$ ) ialah $24,9 \%$ dan memiliki arah pengaruh yang positf, yaitu dengan hasil $\mathrm{Y}=-24,846+1,285 \mathrm{X}$ yang dimana setiap pemberian 
R. Ghefira AS,

bimbingan sebesar 1\% maka akan bertambah pula tingkat kemampuan membaca Al-Qur'an sebesar 1,285\%.

\section{DAFTAR PUSTAKA}

Abdurahmat. 2006. Metodologi Penelitian dan Teknik Pengumpulan Data. Jakarta: PT. Rineka Cipta.

Anshori. 2013. Ulumul Qur'an. Jakarta: Rajawali Press.

Arikunto, Suharsimi. 2010. Prosedur Penelitian: Suatu Pendekatan Praktik. Jakarta: PT Rineka Cipta.

Arikunto, Suharsimi. 2013. Prosedur Penelitian: Suatu Pendekatan Praktik. Jakarta: PT Rineka Cipta.

Departemen Agama RI. 1995. Metode-metode Membaca Al-Qur'an di Sekolah Umum. Jakarta: Direktorat Jenderal Pembinaan Kelembagaan Agama Islam.

Ghozali, Imam. 2005. Aplikasi Analisis Multivariate dengan Program SPSS. Semarang: BP Universitas Diponegoro.

Hallen, A. 2005. Bimbingan dan Konseling. Ciputat: Quantum Teaching.

Jaya, Indra. 2010. Statistik Penelitian Untuk Pendidikan. Bandung: Citapustaka Media Perintis.

Kementrian Pendidikan dan Kebudayaan Pusat Data dan Teknologi Informasi. 2021. APK \& APM Paud, SD, SMP, dan SMA (Termasuk Madrasah Sederajat). Jakarta

Komalasari, Gantina dkk. 2011. Assesment Teknik Non Tes dalam Perspektif BK Komprehensif. Jakarta: PT. Indeks.

Lembaga Ilmu Al-Qur'an Indonesia YASBIQ. 2010. Diktat Training Peningkatan Kompetensi Guru (TPKG). Bandung: LIQA YASBIQ.

M. Nasir Jamil. 2013. Anak Bukan Untuk Dihukum. Jakarta: Sinar Grafika.

Muhadjir Sulthon. 1995. Al-Barqy Buku Belajar Baca Tulis Huruf Al Qur'an. Surabaya: Pena Suci.

Muhidin, Sambas Ali, dan Maman Abdurahman. 2017. Analisis Korelasi, Regresi, dan Jalur Dalam Penelitian Dilengkapi dengan Aplikasi Program SPSS. Bandung: CV. Pustaka Setia.

Mustafa, Syaikh Fuhaim. 2009. Kurikulum Pendidikan Anak Muslim. Surabaya: Pustaka Elba. 
Pengaruh Metode Iqra Terhadap Kemampuan Membaca Al-Qur'an Anak Usia Prasekolah

Nawari. 2010. Analisis Regresi Dengan MS Excel 2007 dan SPSS 17. Jakarta:

Gramedia

Nazir, Moh. 2013. Metode Penelitian. Bogor: Ghalia Indonesia.

Poerwadarminta, W.J.S. 2006. Kamus Umum Bahasa Indonesia. Jakarta: Balai Pustaka.

Prayitno \& Erman Amti. 2004. Dasar-Dasar Bimbingan dan Konseling. Jakarta: PT Rineka Cipta.

Shihab, M. Quraish. 1996. Wawasan Al-Qur'an. Bandung: Mizan.

STID Sirnarasa. 2021. Pedoman Penulisan Skripsi. Ciamis: STID Press.

Subagyo, P. Joko. 2011. Metode Penelitian Dalam Teori dan Praktik Yogyakarta: Aneka Cipta.

Sugiyono. 2010. Metode Penelitian Kuantitatif, Kualitatif, dan R\&D. Bandung: Alfabeta.

Sugiyono. 2013. Metode Penelitian Bisnis (Pendekatan Kuantitatif, Kualitatif, dan $R \& D)$. Bandung: Alfabeta.

Sugiyono. 2013. Metode Penelitian Pendidikan (Pendekatan Kuantitatif, Kualitatif, dan R\&D). Bandung: Alfabeta.

Sugiyono. 2014. Metode Penelitian Kuantitatif, Kualitatif, dan R\&D. Bandung: Alfabeta.

Sugiyono. 2018. Metode Penelitian Kuantitatif. Bandung: Alfabeta.

Suryabrata, Sumadi. 2015. Metodologi Penelitian. Jakarta: Raja Grafindo Persada.

Tim Tadarus Angkatan Muda Masjid dan Musholla (AMM). 1993. Pedoman Pengelolaan TKA-TPA. Yogyakarta: Balai Penelitian dan Pengembangan Sistem Pengajaran Baca Tulis Al Qur'an.

Zuhri, Moh. 1974. Tarjamah Juz Amma. Jakarta: Pustaka Aman

Jamaludin, O. (2021). Peran Pesantren Salafi dalam Peningkatan Kualitas Akhlak Santri: Iktisyaf Jurnal Ilmu Dakwah dan Tasawuf, 3 (1), 86-106.

\section{Sumber Internet}

www.bphn.go.id. UU No. 35 tahun 2014 tentang Perubahan Atas UU No. 23 tahun 2002 tetang Perlindungan Anak. Diakses pada 02 Februari 2021. www.kbbi.co.id. Diakses pada 02 Februari 2021. 